\title{
Simultaneous determination of chloramphenicol and hydrocortisone acetate in cream using TLC desitrometry method
}

\author{
${ }^{*}$ Nia Kristiningrum, Mia Rakhmawati \\ Research and Development Centre in Laboratory of Chemical Pharmacy, University of Jember, East Java, Indonesia
}

\begin{abstract}
A rapid and reproducible TLC method was developed for the determination of hydrocortisone acetate and chloramphenicol in cream. The analytes were dissolved with methanol and chromatographed on silica Gel GF 254 TLC plate using chloroform:ethyl acetate in the ratio of 1:1.5 (v/v) as mobile phase. Spots at Rf 0.29 and Rf 0.59 were recognized as chloramphenicol and hydrocortisone acetate, respectively. Quantitative analysis was done through densitometric measurement at wavelength $265 \mathrm{~nm}$. Method was found linear over the concentration range of 300-900 ng/spot with the correlation coefficient of 0.999 and 0.998 for hydrocortisone acetate and chloramphenicol, respectively. Specificity showed calculation of purity and identity more than 0.99 . The limit of detection (LOD) and the limit of quantification (LOQ) of the method were 23.84 and $71.51 \mathrm{ng} / \mathrm{spot}$ for hydrocortisone acetate, 21.06 and $63.18 \mathrm{ng} / \mathrm{spot}$ for chloramphenicol. The precision of this method was less than $2.8 \%$ whereas the means of the recovery data were $100.40 \pm$ $0.579 \%$ for hydrocortisone acetate and $100.24 \pm 1.20 \%$ for chloramphenicol. The proposed method has been applied to the determination of hydrocortisone acetate and chloramphenicol in commercial cream formulations and the recovery of label claim were $99.23 \pm 0.66 \%$ (chloramphenicol) and $99.25 \pm 0.41 \%$ (hydrocortisone acetate) for brand $\mathrm{A}$ and $100.32 \pm 0.87 \%$ (chloramphenicol) and $100.53 \pm 0.78 \%$ (hydrocortisone acetate) for brand $\mathrm{B}$. The developed method was successfully used for the assay of hydrocortisone acetate and chloramphenicol. The method is simple, sensitive and precise; it can be used for the routine quality control testing of marketed formulations.
\end{abstract}

Key Words: Validation, chromatography, analysis, linearity, reproducible, accuracy.

\section{INTRODUCTION}

Hydrocortisone acetate (Figure 1-A), is a corticosteroid that is able to cope with low potential itching and reduce inflammation caused by dermatitis. Hydrocortisone can prevent or suppress the onset of symptoms of radiation-induced inflammation, infection, chemicals, and allergen (Gunawan et al., 2007). Chloramphenicol (Figure 1-B), an antibiotic, possesses broad spectrum antibacterial activity and is used for the treatment Gram positive and Gram negative bacterial infections. The combination of hydrocortisone acetate and chloramphenicol are used for dermatitis and anti-infection. Many analytical method including spectrophotometric (Blanco et al., 1999) and TLC (Bhawani et al., 2010) have been reported for the determination of hydro-

\footnotetext{
*Corresponding Author:

Nia Kristiningrum, Lecturer

Department of Chemistry, Faculty of Pharmacy

Jember University, Kalimantan street I No 2

Jember, Indonesia 68121

E-mail:neeya_k@yahoo.co.uk

Contact No.: 08123074417
}

cortisone acetate. TLC-densitometry also reported for the estimation of chloramphenicol and prednisolone acetate in their individual and combined pharmaceutical formulations (Musharraf et al., 2012). However, no TLC densitometry method is available for quantitative determination of hydrocortisone acetate and chloramphenicol simultaneously in its pharmaceutical dosage forms. Therefore, it was thought of interest to develop simple, rapid, accurate, specific and precise TLCdensitometry method for determination of hydrocortisone acetate and chloramphenicol simultaneously.

\section{EXPERIMENTAL}

\section{Material and Reagents}

Chloramphenicol working standard (Wuhan Grand Pharmaceutical Group Co., Ltd.), Hydrocortisone acetate (Tianjin Tianyao Pharmaceuticals Co., Ltd.). Methanol, chloroform (Merck) and ethyl acetate 


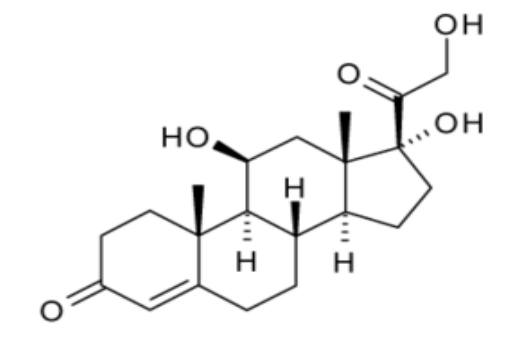

(A)<smiles>O=C(N[C@@H](CO)[C@H](O)c1ccc([N+](=O)[O-])cc1)C(Cl)Cl</smiles>

(B)

Figure 1: Structures of hydrocortisone acetate (A) and chloramphenicol (B).

(Riedel-de Haën). Commercial cream containing hydrocortisone acetate and chloramphenicol.

\section{Preparation of standard solutions and pharmaceu- tical samples}

Stock standard solution was always freshly prepared by dissolving $25 \mathrm{mg}$ of each Hydrocortisone acetate and Chloramphenicol in $25 \mathrm{ml}$ methanol, individually and in combination. Working standard solutions were prepared by dilution of stock solution with methanol to get solutions in concentration range of $150-450 \mathrm{ppm}$. For sample preparation, cream was weighed so that contain equivalent of 2,5 mg Hydrocortisone acetate and 2 $\mathrm{mg}$ chloramphenicol. The cream was dissolved in $25 \mathrm{ml}$ volumetric flask, and approximately $15 \mathrm{ml}$ of methanol was added. The mixture was ultrasonic and diluted to $25 \mathrm{ml}$.

\section{TLC Method and Chromatographic Condition}

Planar chromatography was performed by spotting the sample on precoated TLC silica gel GF $254(20 \mathrm{x}$ $10 \mathrm{~cm}$ ) using $2.0 \mu \mathrm{l}$ glass capillaries. A Camag Twin Through Chamber containing a mixture of chloroform and ethyl acetate (1:1.5) was saturated. The spots move to a distance of $9 \mathrm{~cm}$. Densitometric scanning was performed on Camag TLC Scanner 3 in the absorbance mode at $265 \mathrm{~nm}$ for all measurements. The slit dimension was kept at $6.00 \mathrm{~mm} \times 0.30 \mathrm{~mm}$ and a scanning speed of $20 \mathrm{~mm} / \mathrm{s}$ was employed. Chloramphenicol was detected at $\mathrm{Rf} 0.29$ and

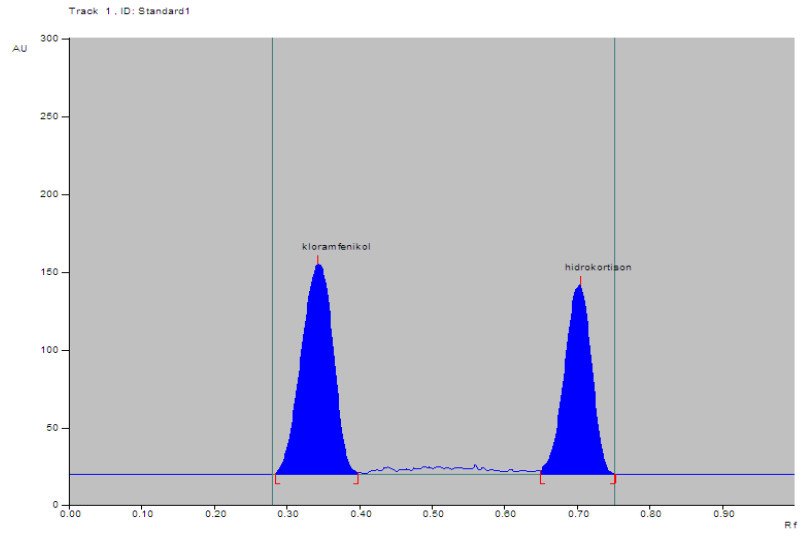

Figure 2: Densitogram of standard chloramphenicol (Rf: $0.29)$ and hydrocortisone acetate ( $R f: 0.59)$, Chloroform : ethyl acetate (1.0: 1.5, v/v).

Hydrocortisone acetate was detected at 0.59. Quantitative evaluation was performed via peak areas by WinCat ${ }^{\circledR}$ software (version 1.4.1.8154).

\section{Method Validation}

The developed method was validated with the following parameters.

\section{Specificity}

The Specificity of this method was determined by analyzing standard and sample. Specificity was showed by purity and identity test that determined by scanning at $200 \mathrm{~nm}-400 \mathrm{~nm}$. Calculations for identity checks ( $r S . S$ and $r \mathrm{~S}, \mathrm{~A}$ where $\mathrm{S}$ is spectrum standard and $\mathrm{A}$ is spectrum sample and purity checks $(r \mathrm{~S}, \mathrm{M}$ and $r \mathrm{M}, \mathrm{E}$ where $\mathrm{S}=$ start, $\mathrm{M}=$ center; and $\mathrm{E}=$ end of spectrum).

\section{Linearity}

The evaluation of the calibration curve's linearity was done based on spots of the standard solutions prepared in methanol at the concentrations 150, 200, 250, 300, 350, 400 and 450 ppm. Peak area was recorded for each concentration and a calibration curve was obtained by plotting peak area vs concentration.

\section{Limit of Detection and Quantification}

Standard solution were prepared at the concentration 20, 30, 40, $50 \mathrm{ppm}, 60$ and $90 \mathrm{ppm}$ and $2 \mu \mathrm{l}$ of each of these solutions was spotted on the TLC plate. Peak area was recorded for each concentration. Limit of detection (LOD) and limit of 
Table 1: Optimum condition for analysis of hydrocortisone acetate and chloramphenicol.

\begin{tabular}{ll}
\hline Parameters & Data \\
\hline Solute & Methanol \\
Eluent & Chloroform : ethyl acetate $=1: 1.5(\mathrm{v} / \mathrm{v})$ \\
Stationary phase & Silica gel GF 254 \\
Wavelength & $265 \mathrm{~nm}$ \\
Concentration & Chloramphenicol $-250 \mathrm{ppm}$ \\
optimum & Hydrocortisone acetate $-200 \mathrm{ppm}$ \\
\hline
\end{tabular}

Table 3: Result of precision evaluation of hydrocortisone acetate.

\begin{tabular}{cc}
\hline Measurement $^{\mathbf{a}}$ & ${\text { RSD value }(\%)(\mathbf{n}=\mathbf{6})^{\mathbf{b}}}^{\mathbf{b}}$ \\
\hline 1 & $0.769 \%$ \\
3 & $1.749 \%$ \\
Average RSD & $1.735 \%$ \\
\hline
\end{tabular}

aEach measurement was perfomed by the same analyst and on a different plate and in different days.

bevaluted by one analyst on one plate (repeatability).

quantification (LOQ) were determined using software validation method version 1.13.

\section{Precision}

The precision of this method was performed by repeatability and intermediate precision studies. Repeatability studies was performed by analyzing one concentration of the drug for six times on the same day. The intermediate precision was checked by repeating studies on three different days.

\section{Accuracy}

The accuracy of this method was evaluated through recovery experiments by adding three different amounts of hydrocortisone acetate and chloramphenicol standards i.e. 40,50 and $60 \%$ of the concentration samples. Each concentration were replicated $(n=3)$.

\section{Analysis of Marketed formulations}

The Samples that is contain of hydrocortisone acetate and chloramphenicol (brand A and brand B) were prepared as sample preparation method. Each of samples were replicated $(n=3)$ and spotted on plates. The analysis was done in the same way as described earlier.
Table 2: Result of precision evaluation of chloramphenicol.

\begin{tabular}{cc}
\hline Measurement $^{\mathbf{a}}$ & RSD value $(\mathbf{\%})(\mathbf{n}=\mathbf{6})^{\mathbf{b}}$ \\
\hline 1 & $1.394 \%$ \\
2 & $1.024 \%$ \\
3 & $1.075 \%$ \\
Average RSD & $1.164 \%$ \\
\hline
\end{tabular}

${ }^{a}$ Each measurement was perfomed by the same analyst and on a different plate and in different days.

bEvaluted by one analyst on one plate (repeatability).

Table 4: Accuracy result of commercial creams.

\begin{tabular}{cccc}
\hline Analyte & $\begin{array}{c}\text { Label claim [\%] } \\
\text { (mean } \pm \text { SD) }\end{array}$ & Added [\%] & Recovery \\
\hline Chloramphenicol & $100.65 \% \pm 1.164$ & $40 \%$ & $100.91 \% \pm 0.57$ \\
& & $50 \%$ & $98.94 \% \pm 0.55$ \\
& $60 \%$ & $100.87 \% \pm 1.15$ \\
acetate & Average recovery \pm SD & $100.24 \% \pm 1.20$ \\
\hline Hydrocortisone & $100.14 \% \pm 1.418$ & $40 \%$ & $100.24 \% \pm 0.40$ \\
& $50 \%$ & $100.76 \% \pm 0.40$ \\
& Average recovery \pm SD & $100.21 \% \pm 0.85$ \\
& $60 \%$ & $10.40 \% 0.57$ \\
\hline
\end{tabular}

\section{RESULTS AND DISCUSSION}

\section{Optimum Condition}

Table 1 shows the optimum conditions for analysis of hydrocortisone acetate and chloramphenicol simultaneously using TLC densitometry. The mobile phase of chloroform : ethyl acetate $(1: 1.5$ $\mathrm{v} / \mathrm{v}$ ) give the efisien chromatogram. Efficiency of chromatogram was evaluated by the value of Number of Theoritical Plate (N), Height Equivalent to a Theoritical Plate $(\mathrm{H})$ and resolution (Rs). The Rf of analytes are 0.29 for chloramphenicol and 0.59 for hydrocortisone acetate (Figure 2). Concentration optimum for hydrocortisone acetate was 200 ppm and chloramphenicol was $250 \mathrm{ppm}$.

\section{Method validation}

From the TLC densitometry, showed that analyte spots in samples were identical with standards. Purity check of the analyte spots using winCATS software also showed that analyte spots were pure.

Table 5: Results of analysis of hydrocortisone acetate and chloramphenicol in pharmaceutical formulation.

\begin{tabular}{lll}
\hline Formulation & $\begin{array}{l}\text { \%Recovery } \pm \text { SD of } \\
\text { chloramphenicol }\end{array}$ & $\begin{array}{l}\text { \%Recovery } \pm \text { SD of } \\
\text { hydrocortisone acetate }\end{array}$ \\
\hline Brand A & $99.23 \% \pm 0.66$ & $99.25 \% \pm 0.41$ \\
Brand B & $100.32 \% \pm 0.87$ & $100.53 \% \pm 0.78$ \\
\hline
\end{tabular}


Table 6: Validation parameters for standard hydrocortisone acetate and chloramphenicol.

\begin{tabular}{cll}
\hline Parameter & Hydrocortisone acetate & Chloramphenicol \\
\hline Specificity & Purity test $\geq 0.99$ Identity test $\geq 0.99$ & Purity test $\geq 0.99$ Identity test $\geq 0.99$ \\
Linierity & $\mathrm{r}=0.999 \mathrm{VxO}=1.423 \%$ & $\mathrm{r}=0.998 \mathrm{VxO}=2.361 \%$ \\
Sensitivity & $\mathrm{LOD}=23.84 \mathrm{ng} / \mathrm{spot} \mathrm{LOQ}=71.51 \mathrm{ng} / \mathrm{spot}$ & $\mathrm{LOD}=21.06 \mathrm{ng} / \mathrm{spot}$ \\
& & $\mathrm{LOQ}=63.18 \mathrm{ng} / \mathrm{spot}$ \\
& & Average $\mathrm{RSD}=1.164 \%$ \\
Precision & Average $\mathrm{RSD}=1.418 \%$ & Average recovery $\pm \mathrm{SD}=100.24 \pm 1.2 \%$ \\
\hline
\end{tabular}

The values of $\mathrm{rS}, \mathrm{M}$ and $\mathrm{rM}, \mathrm{E}$ were $>0.999$, demonstrating that proposed TLC method is highly specific. Linearity of Hydrocortisone acetate gave the equation $Y=669.882+5.889 \mathrm{X}$ with correlation coefficient $\left(\mathrm{r}^{2}\right)$ value of 0.999 . Linearity of Chloramphenicol gave the equation $\mathrm{Y}=864.717+6.774 \mathrm{X}$ correlation coefficient $\left(\mathrm{r}^{2}\right)$ value of 0.998 . The LOD and LOQ (Limit of Detection and Quantification) were found to be $11.918 \mathrm{ppm}$ and $35.754 \mathrm{ppm}$ for hydrocortisone acetate, $10.530 \mathrm{ppm}$ and $31.590 \mathrm{ppm}$ for chloramphenicol. All the values of the repeatability and intermediate precision evaluation were less than $2.8 \%$ (table 2 and 3). The three measurements were performed within one laboratory by same analyst on different plates and in different days. The accuracy of the proposed method were $100.40 \pm 0.57 \%$ for hydrocortisone acetate and $100.24 \pm 1.20 \%$ for chloramphenicol (table 4 ). The summary of data validation parameters is listed in table 6.

\section{Analysis of Marketed formulations}

The result of the analysis of marketed formulations brand $\mathrm{A}$ and brand $\mathrm{B}$ showed that there was no interference from the excipients. The result given in table 5 indicate that the concentrations of hydrocortisone acetate and chloramphenicol in cream is within the requirements (USP) $90-110 \%$ for hydrocortisone acetate and $90-130 \%$ for chloramphenicol.

\section{CONCLUSION}

A new TLC method has been developed for the identification and quantification of hydrocortisone acetate and chloramphenicol in cream simultaneously. The method was found to be simple, rapid, specific, sensitive, precise and accurate for estimation and can be conveniently employed for the routine quality control analysis hydrocortisone acetate and chloramphenicol in cream.

\section{REFERENCES}

Bhawani, S.A., Sulaiman, O., Hashim, R., Mohamad Ibrahim, M.N. (2010) Thin Layer Chromatographic Analysis of Steroids : A Review. Tropical Journal of Pharmaceutical Research, 9 (3): 301-312. [DOI]

Blanco, M., Coello, J., Iturriaga, H., Maspoch, S., Villegas, N. (1999) Kinetic Spectrophotometric Dertermination of Hydrocortisone Acetate in a Pharmaceutical Preparation by Use of Partial Least - Squares Regression, Analyst, 124 : 911-915. [DOI]

Gunawan, S.G., Setiabudy, R., Nafrialdi dan Elysabeth. (2007) Farmakologi dan Terapi Edisi 5. Jakarta: FKUI.

Musharraf, S.G., Fatima, U., Sultana, R. (2012) Stress Degradation Studies and Development of Stability Indicating TLC - densitometry Method for Determination of Prednisolone Acetate and Chloramphenicol in Their Individual and Combined Pharmaceutical Formulations, Chemistry Central Journal, 6 (7) : 2-9.

The United State Pharmacopoeia 25-National Formulary 20. Asia Edition. Rockville: United State Pharmacopoeial Convention. 